\title{
Perancangan Perahu Nelayan Ramah Lingkungan Menggunakan Motor Listrik Bertenaga Surya
}

\author{
Belly Yan Dewantara ${ }^{1}$, Iradiratu D.P.K ${ }^{2}$, Daeng Rahmatullah ${ }^{3,}$ dan Istiyo Winarno ${ }^{4}$ \\ Jurusan Teknik Elektro, Fakultas Teknik dan Ilmu Kelautan \\ Universitas Hang Tuah Surabaya ${ }^{1,2,3,4}$ \\ e-mail: bellyyandewantara@yahoo.com,iradiratu@hangtuah.ac.id, \\ daengrahmatullah@gmail.com, istiyo.winarno@gmail.com
}

\begin{abstract}
Abstrak - Penggerak perahu nelayan secara umum menggunakan mesin tempel yang menggunakan energi fosil (bahan bakar minyak bumi/BBM). Penggunaan BBM semakin banyak, dapat menyebabkan polusi udara. Sejalan dengan ini pemerintah juga mencanangkan hemat BBM dan BBM sudah tidak ada subsidi lagi. Hal ini menyebabkan biaya operasional bagi pengguna mesin tempel perahu nelayan semakin besar. Selain itu mesin perahu nelayan dengan menggunakan BBM dapat menimbulkan suara bising yang merambat ke dalam air laut, sehingga ikan bergerak menjauhi perahu. Hal ini menjadi kendala yang harus dipecahkan. Kendala-kendala ini dapat diantisipasi dengan mengganti mesin tersebut dengan mesin DC. Mesin DC sebagai penggerak perahu menggunakan listrik DC yang di suplai menggunakan baterao sehingga tidak menimbulkan suara bising dan tidak membuat ikan menjauh dari perahu nelayan. Pada penelitian ini akan diterapkan juga sumber listrik ramah lingkungan menggunakan tenaga matahari untuk sumber listrik pengisian baterai motor sehingga penggunaan perahu nelayan dapat lebih lama dan nelayan tidak perlu khawatir kehabisan daya listrik selama panel surya mendapat paparan energy matahari. Perahu nelayan dengan penggerak motor listrik nantinya akan dilengkapi beberapa komponen antara lain 2 buah solar cell $100 \mathrm{WP}, 1$ buah baterai $100 \mathrm{Ah}$, dan motor listrik daya 500 watt.
\end{abstract}

Kata kunci : Surya, Motor DC, Energi Terbarukan, Perahu Nelayan.

Abstract - The driver of a fishing boat generally uses an outboard engine that uses fossil energy (petroleum / fuel). Increasing use of fuel, can cause air pollution. In line with this, the government has also planned to save fuel and fuel no more subsidies. This causes the operational costs for users of fishing boat outboard engines to increase. In addition, the fishing boat engine using fuel can cause noise that propagates into the sea water, so the fish moves away from the boat. This is an obstacle that must be solved. These obstacles can be anticipated by replacing the engine with a DC engine. The DC engine as a boat driver uses DC electricity which is supplied using batteries so it does not cause noise and does not keep the fish away from the fishing boat. In this research, environmentally friendly electricity sources will also be used using solar energy for motorbike charging, so that the use of fishing boats can be longer and fishermen do not have to worry about running out of electricity as long as solar panels get sun exposure. A fishing boat with an electric motor drive will be equipped with several components including $2100 \mathrm{WP}$ solar cells, $1100 \mathrm{Ah}$ battery, and a 500 watt electric motor.

Keywords: Solar, DC motors, renewable energy, fishing boats.

Keywords : Solar, DC Motors, Renewable Energy, Fishing Boats.

\section{PENDAHULUAN}

Saat ini perkembangan teknologi perkapalan di Indonesia telah mencapai kemajuan tingkat internasional, perkembangan dibidang perkapalan tersebut merupakan bagian dari pengembangan teknologi pada umumnya di Indonesia. Usaha untuk mengembangkan, menerapkan dan menguasai teknologi perkapalan telah dilakukan secara terencana, tertib dan terarah dengan memanfaatkan semua sumber daya yang dimiliki. Pengembangan teknologi perkapalan ini sudah cukup maju dan merupakan indikasi kemampuan penguasaan teknologi dalam bidang kelautan.

Umumnya perahu nelayan menggunakan mesin diesel sebagai tenaga penggerak baling-baling atau propeler, namun penggunaan mesin diesel sebagai tenaga penggerak baling-baling memiliki beberapa permasalahan dan kelemahan, antara lain: menimbulkan kebisingan sehingga membuat ikan menjauh dari perahu nelayan, harga bahan bakar semakin mahal. Oleh karena itu untuk mengatasi permasalahan tersebut, perlu adanya alternatif mesin yang digunakan sebagai penggerak perahu. Sebagai salah satu 
alternatif pemecahan masalah tersebut, maka perlu dikaji penggunaan motor listrik sebagai penggerak kapal.

Kelemahan dari penggunaan motor listrik di perahu nelayan adalah sumber kelistrikan untuk menyuplai motor listrik masih menggunakan baterai/aki sehingga penggunaannya sangat terbatas, maka dari itu dalam penelitian ini dilakukan penerapan penggunakan panel surya yang memanfaat energi matahari sebagai sumber kelistrikan untuk pengisian ulang baterai/aki pada perahu nelayan.

Dalam penyelesaian masalah tersebut maka beberapa analisa yang dilakukan adalah bagaimana membuat alternative penggerak pada perahu nelayan dengan menggunakan motor listrik dan bagaimana cara memanfaatkan energi terbarukan khususnya energi matahari dalam mendukung kebutuhan sumber listrik pada perahu nelayan.

Tujuan yang ingin dicapai dalam pembuatan penelitian ini adalah untuk merencanakan, merancang dan membuat perahu nelayan yang menggunakan penggerak motor listrik dengan memanfaatkan energi matahari sebagai sumber kelistrikan yang digunakan untuk charging baterai dan kebutuhan kelistrikan lainnya.

Sehingga nantinya dapat memberikan manfaat pengaplikasian energi terbarukan khususnya energi matahari dalam bidang kemaritiman dan juga memberikan solusi alternatif bagi nelayan untuk menggunakan penggerak perahu dengan sumber energi yang ramah lingkungan.

\section{METODE PENELITIHAN}

Dalam pengerjaan penelitian ini perlu adanya rancangan metodologi dalam penyelesaian penelitian ini adalah:

1. Tahap Pertama Pengumpulan Data.

Studi literatur, pembuatan, perancangan system propulsi dan penulisan penelitian ini berdasarkan literatur- literatur, jurnal dan lain-lain.

2. Tahap Kedua Pembuatan Perahu Nelayan

Penentuan ukuran utama perahu. Untuk menentukan ukuran perahu didasarkan pada, bahwa perahu ini sebagai perahu untuk nelayan, Perancangan dan Pembuatan perahu nelayan dengan jumlah penumpang maksimal 2 orang, dengan beban yang lain yaitu poros, motor listrik tempel, modul solar cell 2x100 wp, tiang, baterai 12 volt 100ah dan sistem kemudi.

Pembuatan rencanan umum. Pengambaran rencana umum berdasarkan bentuk lambung yang diperoleh dari rencana garis dan disesuaikan dengan pemanfaatan ruang perahu.

Pembuatan body perahu. Dengan bahan fiberglas dilakukan lapisan demi lapisan sehingga untuk panjang perahu rencana menggunakan 4 lapisan

3. Tahap Ketiga Pemasangan Komponen

Pemasangan Modul sel surya dan sistem propulasi. Pemasangan tiang-tiang penyangga modul sel surya. Pemasangan system propulasi yaitu steam turbine, poros, propeller, motor dan baterai. Pemasangan system kemudi dan instalasinya. Pemasangan tempat duduk baik pengemudi maupun penumpang.

4. Tahap Keempat Pengujian Perahu. berikut:

Dari data ukuran utama perahu diperoleh hal-hal

Perhitungan tahanan perahu dengan metode Holtrop menghasilkan komponen tahanan gesek, tahanan transom, tahanan gelombang dan tahanan total. Grafik hubungan antara tahanan total dengan daya efektif. Penentuan parameter propulsi, daya listrik dari sel surya dan laju pengisian baterey (aki).

5. Tahap Kelima Pembahasan Hasil. Penelitian.

Jumlah jam eksploitasi perahu. Konfigurasi system sel surya (solar cell)

\section{HASIL DAN PEMBAHASAN}

Secara garis besar, jenis penelitian yang digunakan adalah eksperimental. Adapun beberapa aspek yang penting dalam penelitian ini antara lain memperhatikan aspek karakteristik komponen yang digunakan, sehingga bisa membuat perahu listrik yang akan didesain sesuai dengan target sasaran yang diinginkan. Berikut merupakan bagian bagian penting dalam penelitian ini:

\section{Perancangan perahu nelayan}

Perahu nelayan yang akan dibuat berukuran sedang dengan daya tampung maksimum 2 orang, dimensi panjang perahu dibuat 3 meter dengan demikian Lebar, Sarat dan Tinggi perahu dapat diperoleh dari rasio perbadingan ukuran perahu sebagai berikut :

$$
\begin{array}{ll}
\mathrm{L} / \mathrm{B} & =3,0-4,0 \\
3 / \mathrm{B} & =3,0 \\
\mathrm{~B} & =1,00 \mathrm{~m}=100 \mathrm{~cm} \\
\mathrm{~B} / \mathrm{T} & =2,7-4,8 \\
1,00 / \mathrm{T} & =3,30 \\
\mathrm{~T} & =0,30 \mathrm{~m}=30 \mathrm{~cm}
\end{array}
$$

Pada umumnya lebar perahu kurang lebih 1,80 tinggi perahu sehingga tinggi perahu dapat diperoleh sebesar :

$$
\begin{aligned}
\mathrm{B} & =1,80 . \mathrm{H} \\
\mathrm{H} & =1,00 / 1,80 \\
\mathrm{H} & =0,55 \mathrm{~m}=55 \mathrm{~cm}
\end{aligned}
$$

Dengan demikian dapat disimpulkan bahwa ukuran utama perahu rancangan adalah sebagai berikut :

$$
\begin{array}{ll}
\text { Panjang ( L ) } & =3,0 \mathrm{~m}=300 \mathrm{~cm} \\
\text { Lebar ( B ) } & =1,00 \mathrm{~m}=100 \mathrm{~cm} \\
\text { Sarat }(\mathrm{T}) & =0,30 \mathrm{~m}=30 \mathrm{~cm} \\
\text { Tinggi }(\mathrm{H}) & =0,55 \mathrm{~m}=55 \mathrm{~cm}
\end{array}
$$

Perahu nelayan yang akan dibuat berukuran sedang dengan daya tampung maksimum 2 orang, dimensi panjang perahu dibuat 3 meter dengan demikian Lebar, 
Sarat dan Tinggi perahu dapat diperoleh dari rasio perbadingan ukuran perahu sebagai berikut :

$$
\begin{array}{ll}
\mathrm{L} / \mathrm{B} & =3,0-4,0 \\
3 / \mathrm{B} & =3,0 \\
\mathrm{~B} & =1,00 \mathrm{~m}=100 \mathrm{~cm} \\
\mathrm{~B} / \mathrm{T} & =2,7-4,8 \\
1,00 / \mathrm{T} & =3,30 \\
\mathrm{~T} & =0,30 \mathrm{~m}=30 \mathrm{~cm}
\end{array}
$$

Pada umumnya lebar perahu kurang lebih 1,80 tinggi perahu sehingga tinggi perahu dapat diperoleh sebesar :

$$
\begin{array}{ll}
\mathrm{B} & =1,80 . \mathrm{H} \\
\mathrm{H} & =1,00 / 1,80 \\
\mathrm{H} & =0,55 \mathrm{~m}=55 \mathrm{~cm}
\end{array}
$$

Dengan demikian dapat disimpulkan bahwa ukuran utama perahu rancangan adalah sebagai berikut :

$$
\begin{array}{ll}
\text { Panjang ( L ) } & =3,0 \mathrm{~m}=300 \mathrm{~cm} \\
\text { Lebar ( B ) } & =1,00 \mathrm{~m}=100 \mathrm{~cm} \\
\text { Sarat ( T ) } & =0,30 \mathrm{~m}=30 \mathrm{~cm} \\
\text { Tinggi }(\mathrm{H}) & =0,55 \mathrm{~m}=55 \mathrm{~cm}
\end{array}
$$

\section{Pemilihan Motor Listrik}

Pada penelitian ini kecepatan laju perahu tidak diprioritaskan dikarenakan penggunaan hanya untuk nelayan. Motor listrik yang akan digunakan berupa motor DC dengan rate tegangan $12 \mathrm{~V}$ dengan kapasitas 450 watt. Berdasarkan paper [2] tentang kebutuhan daya dalam kecepatan kapal makan konsumsi daya 450 watt dapat digunakan untuk kecepatan 2-3 knot. Berikut merupakan spesifikasi lengkap motor listrik yang akan digunakan :

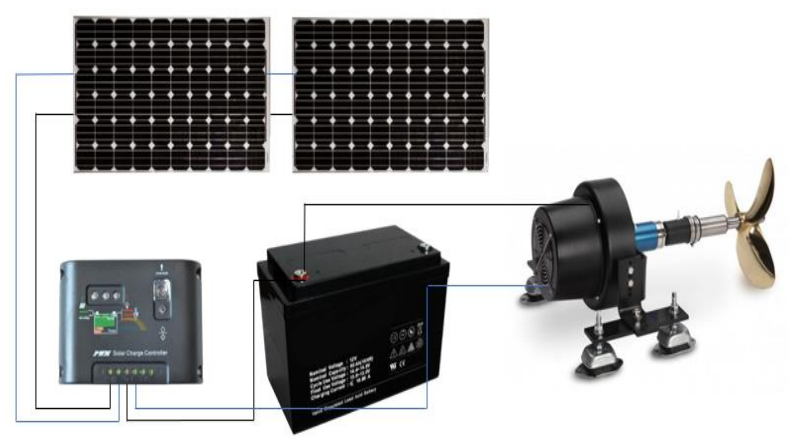

Gambar 1. Desain motor listrik tenaga surya

Tabel 1. Spesdifikasi motor listrik

\begin{tabular}{|c|c|}
\hline \multicolumn{2}{|c|}{ Spesifikasi } \\
\hline Fuel Type & Electric \\
\hline Tenaga & $500 \mathrm{watt}$ \\
\hline Voltage & 12 Voltage \\
\hline Berat Produck & $15 \mathrm{~kg}$ \\
\hline Berat Packing & $15.63 \mathrm{~kg}$ \\
\hline
\end{tabular}

3. Perhitungan Nilai Baterai Perahu Nelayan

Dalam pemilihan baterai harus disesuaikan dengan kebutuhan daya. Dalam perencanaan kebutuhan listrik yang akan disuplai oleh panel surya ke baterai difokuskan untuk kebutuhan listrik motor penggerak propeller perahu. Baterai yang digunakan sebagai sumber listrik untuk motor listrik pada perahu ini adalah aki jenis deep cycle 12 volt sehingga bisa secara langsung digunakan oleh motor karena memiliki rate tegangan yang sama tanpa memerlukan adanya converter tambahan lainnya.

Perahu ini didesain dengan penggunaan per harinya selama 2 jam, maka dibutuhkan kapasitas baterai yang dapat menyuplai listrik selama 2 jam terhadap mesin penggerak.

Baterai $=2$ jam $x 500$ watt

$$
=1000 \mathrm{watt}
$$

Berdasarkan kebutuhan kapasitas baterai tersebut maka baterai yang digunakan adalah dengan sebagai berikut:

Tabel 2. Spesifikasi Baterai

\begin{tabular}{|c|c|}
\hline Spesifikasi & Keterangan \\
\hline Nominal Voltage & $12 \mathrm{~V}$ \\
\hline Rated Capacity & $100 \mathrm{Ah}$ \\
\hline Model & VRLA Battery \\
\hline Dimension $(\mathrm{cm})$ & $33 \times 17.5 \times 24$ \\
\hline Weight & $30.75 \mathrm{Kg}$ \\
\hline
\end{tabular}

\section{Pemilihan Nilai Panel Surya}

Panel surya yang digunakan dalam penelitian ini adalah panel surya dengan kapasitas 100 wp yang nantinya ditempatkan diatas perahu sekaligus sebagai atap perahu. Berikut jenis panel surya yag digunakan:

Tabel 3. Spesifikasi Panel Surya

\begin{tabular}{|l|}
\hline 100 W MONO- CRYSTALLINE SOLAR PANEL \\
\hline Peak Power : $100 \mathrm{~W}$ \\
\hline Grade $:$ A \\
\hline Merk : Solarimba \\
\hline Power Tolerance $(\%):+/-3 \%$ \\
\hline Cell Efficiency : $18 \%$ \\
\hline Open Circuit Voltage (Voc) $: 21.6 \mathrm{~V}$ \\
\hline Short Circuit Current (Isc) $: 6.1 \mathrm{~A}$ \\
\hline Maximum Power Voltage $(\mathrm{Vmp}): 18 \mathrm{~V}$ \\
\hline Maximum Power Current $(\mathrm{Imp}): 5.56 \mathrm{~A}$ \\
\hline Number of Cell $(\mathrm{Pcs}): 36(4 \times 9)$ Pcs \\
\hline Operating Temperature $(\mathrm{C}):-40 \mathrm{C}$ to $+85 \mathrm{C}$ \\
\hline Dimensions $(\mathrm{mm}): 1196 \mathrm{x} 541 \times 30 \mathrm{~mm}$ \\
\hline Weights $(\mathrm{Kg}): 7 \mathrm{Kg}$ \\
\hline
\end{tabular}

Penggunaan panel surya dengan kapasitas 100 wp terbatas oleh jumlah, karena luas kapal hanya 300 x 100 $\mathrm{cm}$ maka penggunaan panel surya hanya bisa sebanyak 2 buah panel dengan ukuran 119x54 cm per ukuran panel surya.

Berdasarkan [3] penyinaran maksimal matahari di Indonesia dalam satu hari hanya 3 jam, maka dapat ditentukan panel surya dapat menyuplai listrik:

$$
\begin{aligned}
\text { Jumlah }= & 3 \text { jam } \times(2 \text { buah } \times 100 w p) \\
& =600 \text { watt }
\end{aligned}
$$

Maka dalam satu hari panel surya mampu mengisi baterai sebanyak 60\% dari kapasitas penuh 1000 watt (efisiensi 
baterai $80 \%$ ). Untuk menggunakan perahu dengan penggerak mesin listrik selama 2 jam dibutuhkan penyimpanan atau pengisian daya baterai oleh panel surya selama 2 hari sehingga baterai terisi penuh dan dapat digunakan optimal oleh mesin perahu.

\section{Perencanaan Pemilihan Nilai Solar Charge Control}

Solar charge control yang dipilih merupakan jenis PWM dikarenakan untuk daya dibawah 200 watt lebih efisien menggunakan SCC jenis PWM.

Berikut merupakan spesifikasi solar charge control yang digunakan :

Tabel 4. Spesifikasi SCC

STEC PWM Solar Charge Controller LCD USB 20A

Rated Voltage: $12 \mathrm{~V} / 24 \mathrm{~V}$ (Auto recognition)

Rated Current: 20A

Charging Mode: PWM

USB output: $5 \mathrm{~V} / 3 \mathrm{~A}$

Self-consume: $10 \mathrm{~mA}$

Operating Temperature: $-35 \sim 60$ '"

Storage Temperature: $-35 \sim 60$ "'

Color: Blue (As pictures show)

Nilai kerja dari SCC ditentukan berdasarkan Isc pada panel surya. Jika kita lihat pada spesifikasi panel surya Isc untuk 1 buah panel surya adalah 6,1 A, dan karena kebutuhan baterai yang digunakan adalah baterai dengan tegangan kerja $12 \mathrm{~V}$ maka, 2 buah panel surya harus dihubungkan parallel sehingga menghasilkan tegangan tetap namun arus meningkat menjadi $2 \times$ Isc panel surya $=$ 12,2 A. Maka dari itu diperlukan kontroler surya yang dapat dilalui arus sebesar 12,2 A, pada penelitian ini digunakan SCC sebesar 20 A.

\section{KESIMPULAN}

1. Dengan penggunaan jumlah panel surya yang terbatas berdampak pada pengisian baterai yang lama, untuk memenuhi baterai dengan kapasitas 12V 100Ah memerlukan waktu 5 jam. Sedangkan penyerapan maksimal panel surya hanya 3 jam per hari. Sehingga dibutuhkan waktu 2 hari agar baterai terisi penuh.

2. dalam penyerapan satu hari hanya mampu digunakan perahu beroperasi selama 1 jam.

3. Penggunaan baterai 100Ah tipe deep cycle VRLA pada perahu tidak cocok karena memiliki bobot terlalu berat yang menjadi hambatan beban kerja mesin.

4. Penggunaan panel surya jenis kontruksi fixed juga menambah beban berlebih pada mesin, akan lebih mengurangi beban motor jika menggunakan jenis yang fleksibel.

\section{REFERENSI}

[1] Jha, A.R. (2010). Solar cell technology and applications, Taylor and Francis Group, LLC. London

[2] Tiwari, G. N., \& Swapnil, D. (2009). Fundamentals of Photovoltaic Modules and Their Aplications.

[3] Winarni, D. (1997). Studi tentang perencanaan pada Kalimas dan hubungannya dengan perilaku masyarakat disekelilingnya, ITS-Surabaya.

[4] Captain, D. R. Derrett. (2001). Ship Stability for Masters and Mates, Fifth edition, Butterworth Heinema.

[5] Sarwono. (1990). Analisa Kualitas Sel Surya Sebagai Pembangkit Tenaga Listrik Skala Laboratorium, ITSSurabaya.

[6] F, Lumenta. (1997). Optimasi Dalam Penentuan Ukuran Pokok kapal-kapal Rakyat Di Maluku, Jurnal Ilmu Pengetahuan dan Teknologi Universitas Pattimura, Volume 2. 